\title{
AUSTENITE SOFTENING IN THE FINISHING STAGE OF T.M.C.P. OF HIGH NIOBIUM-LOW MANGANESE MICROALLOYED STEELS
}

\author{
Antonio Augusto Gorni ${ }^{\prime}$ \\ José Herbert Dolabela da Silveira ${ }^{2}$ \\ Kenji Camey ' \\ Emanuelle Garcia Reis ${ }^{2}$
}

\begin{abstract}
Recently several studies have been developed on the use of microalloyed steels with low Mn content (below I\%) in the controlled rolling of heavy plates for the manufacture of pipes. However, lower Mn contents should lead to the acceleration of $\mathrm{NbCN}$ precipitation kinetics during rolling, reducing the soluble $\mathrm{Nb}$ content in austenite. This fact, plus the heavy and fast passes applied under virtually isothermal conditions in a heavy plate rolling mill, increases the risk of partial recrystallization during the finishing stage of the controlled rolling, since strain hardening of austenite becomes significant and the interaction between precipitation and recrystallization is increasingly delayed. The objective of this study was to analyze the evolution of mean flow stress during the finishing stage of controlled rolling in these low Mn, high $\mathrm{Nb}$ microalloyed steels to better understand the metallurgical mechanisms acting during this process.
\end{abstract}

Keywords: Controlled Rolling; Low Mn high Nb microalloyed steels; Austenite recrystallization; NbCN precipitation.

\section{AMACIAMENTO DA AUSTENITA DURANTE A FASE DE ACABAMENTO DO PROCESSAMENTO TERMOMECÂNICO DE AÇOS MICROLIGADOS COM ALTO NIÓBIO E BAIXO MANGANÊS}

\section{Resumo}

Recentemente foram desenvolvidos estudos sobre o uso de aços microligados com baixo teor de Mn (abaixo de I\%) na laminação controlada de chapas grossas para a manufatura de tubos de grande diâmetro. Contudo, menores teores de Mn podem levar à aceleração da precipitação de $\mathrm{NbCN}$ durante a laminação, levando a uma redução no teor de $\mathrm{Nb}$ solúvel presente na austenita. Este fato, mais os rápidos e pesados passes aplicados sob condições virtualmente isotérmicas num laminador de chapas grossas, aumentam o risco de recristalização durante a fase de acabamento da laminação controlada, já que o encruamento da austenita se torna significativo e a interação entre precipitação e recristalização é cada vez mais atrasada. O objetivo desse estudo consistiu em analisar a evolução da resistência média à deformação durante a fase de acabamento da laminação controlada nestes aços com baixo $\mathrm{Mn}$ e alto $\mathrm{Nb}$ para se entender melhor os mecanismos metalúrgicos que atuam durante esse processo.

Palavras-chave: Laminação controlada; Aços microligados com baixo Mn e alto Nb; Recristalização da austenita; Precipitação de $\mathrm{NbCN}$.

\section{INTRODUCTION}

The use of $\mathrm{Mn}$ as an alloying element in steels has been virtually unquestionable for decades due to its relatively low cost and the benefits it provides, such as increased hardenability and hot ductility. Its usefulness has further increased with the advent of the so called Advanced High Strength Steels (AHSS), where its role is even more important. To crown this evolution, it is a key alloying element in twinning-induced plasticity (TWIP) steels, where its amount is in the $20-22 \%$ range.

But, as one would expect, so much success ends up with disadvantages [I]. The increase in demand for manganese obviously can lead to a significant increase in the price of its ferroalloys, so its replacement is already being studied in technically viable cases. Recent studies

'Gerência de Pesquisa e Desenvolvimento, Gerdau Ouro Branco, Ouro Branco MG, Brazil. E-mail: antonio.gorni@gmail.com

${ }^{2}$ Gerência de Chapas Grossas, Gerdau Ouro Branco, Ouro Branco MG, Brasil.

2176-1523 (C) 2020. Pareda. Published by ABM. This is an Open Access article distributed under the terms of the Creative Commons Attribution License, which permits unrestricted use, distribution, and reproduction in any medium, provided the original work is properly cited. 
advocate its replacement by $\mathrm{Nb}$ microadditions, which have been done with good results both in technical and economic terms [2]. Other advantages resulting from the lowering of the Mn content, these already known for a long time, are the reduction of the load of ferroalloys in the ladle and the consequent loss of heat by the liquid steel and lower contamination by P, as well minimization of central segregation intensity in slabs and microstructural banding in the final products [3]. These advantages, plus the increase in the solubility of $S$ in austenite, which minimizes or even suppresses the nucleation of $\mathrm{MnS}$, constitute the basis for a relatively new type of steel used in heavy plates for the manufacture of sour service pipes, which combines extra-low $\mathrm{Mn}$ and significant $\mathrm{Nb}$ contents [4].

Although the new low Mn steel compositions are balanced in order to maintain or even improve the performance of the final products, their peculiar alloy design influences their metallurgical response during its thermomechanical controlled processing (TMCP), as discussed below.

Maehara, in an early work [5], showed that the increase in $\mathrm{Mn}$ content slows down the kinetics of austenite static recrystallization at $900^{\circ} \mathrm{C}$ in $\mathrm{CMn}$ steels, occurring saturation of this effect when its content approaches values about $1 \%$. The effect of $\mathrm{Mn}$ on the retardation of austenite recrystallization kinetics in $\mathrm{Nb}$ microalloyed steels was also studied, but considering exclusively their drag effect as dissolved atoms, a situation which occurs during the roughing stage of controlled rolling, where there is no $\mathrm{NbCN}$ precipitation due to the high rolling temperatures. Cho et al. [6] proposed several equations to quantify the effect of $\mathrm{Mn}$ on the kinetics of austenite recrystallization in a low $C$ steel containing $0.050 \% \mathrm{Nb}$. In general, the equations proposed by him to calculate the time required for $50 \%$ static or metadynamic recrystallization of austenite indicate that the corresponding activation energy values were directly proportional to the $\mathrm{Mn}$ content of the steel in the range between 0.5 and $1.5 \%$. For its turn, Lotter et al. [7] proposed an equation to calculate the time required by $50 \%$ of austenite recrystallization which simultaneously includes the effect of $\mathrm{Mn}$ and $\mathrm{Nb}$, both contributing to increase the activation energy of this restoration process.

On the other hand, the effect of $\mathrm{Mn}$ on austenite recrystallization in microalloyed $\mathrm{Nb}$ steels is more complex at temperatures low enough for $\mathrm{NbCN}$ precipitation to occur. It is necessary to consider the mutual interaction between these two elements: $\mathrm{Mn}$ increases the stability of $\mathrm{Nb}$ in austenite, promoting its solubilization [8], and increasingly hinders its precipitation to a content of approximately 1.9\%, when the effect stabilizes [9].

So, it seems logical to expect that, in $\mathrm{Nb}$ microalloyed steels with low levels of Mn, where precipitation would occur more quickly, there would be less time available for the occurrence of recrystallization, increasing its softening resistance. As a matter of fact, it was found in these steels that the faster $\mathrm{Nb}$ precipitation raises the temperature of no-recrystallization $\left(\mathrm{T}_{\mathrm{nr}}\right)$ due to the occurrence of $\mathrm{Nb}$ precipitation at higher temperatures. However, this early and intensified precipitation, plus the faster precipitate growth, already in the roughing stage of TMCP, may eventually deplete $\mathrm{Nb}$ dissolved in austenite in the finishing stage, reducing its drag effect and easing recrystallization [ 10$]$.

It was also verified in steels with low Mn content that the immediate and extensive nucleation of $\mathrm{NbCN}$ precipitates over the dislocations present in the strained austenite promotes their pinning, which restricts or delays austenite recovery $[11,12]$. For its turn, recovery suppression increases the thermodynamic potential for the subsequent recrystallization. In addition, lower Mn contents exert less drag effect on the recrystallization fronts [5]. All these factors can accelerate softening kinetics, so it could start before the beginning of $\mathrm{NbCN}$ precipitation.

Thus, it is plausible to conceive a pass schedule under slightly decreasing temperatures during the finishing stage of controlled rolling where the increase in the thermodynamic potential of austenite recrystallization resulting from the recovery blocked by intensified $\mathrm{NbCN}$ precipitation, associated with the impoverishment of soluble $\mathrm{Nb}$ that this causes in austenite, and the accumulation of strain hardening at each pass, ends up enabling austenite recrystallization, even if partial, at relatively low temperatures.

The analysis of mean flow stress values calculated from hot rolling loads in the finishing stage of industrial controlled rolling of a microalloyed steel with $\mathrm{Mn}$ content less than $1.0 \%, C$ less than $0.05 \%$ and $\mathrm{Nb}$ greater than $0.060 \%$ revealed a consistent softening occurrence at the third finishing pass (F3). This fact was unusual, since the finishing stage had started around $940-970^{\circ} \mathrm{C}$, well below the of $\mathrm{T}_{\mathrm{nr}}$ experimentally determined by a multiple hot torsion test for a similar steel, $1070^{\circ} \mathrm{C}$ [13], according to the procedure proposed by Boratto et al. [14], as shown in Figure I. It should be noted that the difference between $T_{n r}$ measured in the laboratory and the finishing start temperature adopted in the industrial controlled rolling was

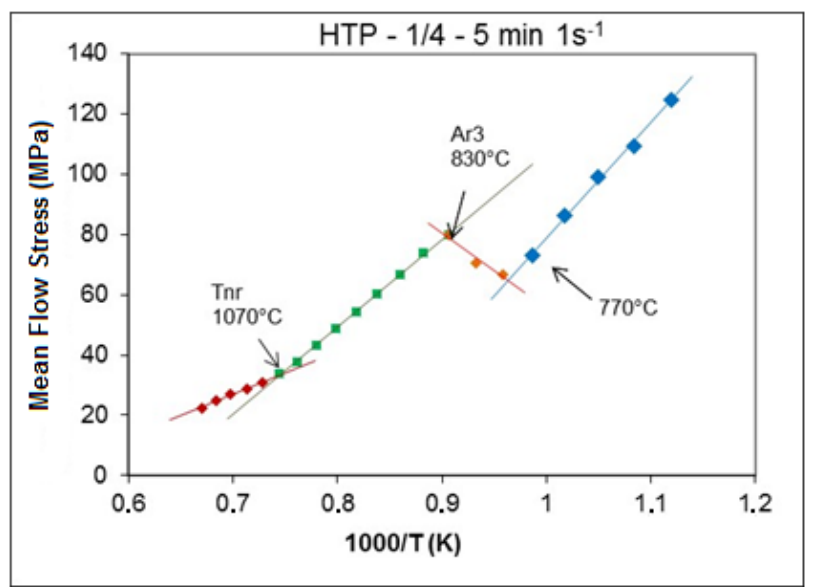

Figure I. Austenite critical temperatures for a high $\mathrm{Nb}$ microalloyed steel with low Mn content [13]. 
above $75^{\circ} \mathrm{C}$, as recommended by Bai et al. [15]. Another intriguing fact was the absence of softening of austenite in the laboratory test.

It is widely known that any occurrence of austenite recrystallization during the finishing stage of controlled rolling is undesirable, as it affects the homogeneity of the grain size distribution in the microstructure of the final plate. This, for its turn, potentially impairs its toughness features. So, it was decided to develop this work to better understand the origin of this phenomenon and identify its countermeasures.

\section{MATERIAL AND METHODS}

Slabs with $250 \mathrm{~mm}$ thickness, made of microalloyed steel with Mn content lower than I.0\%, C lower than $0.05 \%$ and $\mathrm{Nb}$ higher than $0.060 \%$, were controlled rolled to $20 \mathrm{~mm}$ plates. After roughing and a holding stage, the finishing stage started at temperatures between 940 and $970^{\circ} \mathrm{C}$, except where otherwise noted. Mean Flow Stress (MFS) values corresponding to each rolling pass were calculated using process data routinely available at the plate mill supervisory system. The following Formula I was used:

$$
M F S=\frac{P}{w \sqrt{R \Delta h} Q}
$$

where $P$ is the rolling load; $w$ is the width of the rolling stock; $R$ is the radius of the work rolls; $\Delta h$ is the difference between the initial and final thicknesses of the rolling stock; and $\mathrm{Q}$ is a dimensionless factor defined by the model to calculate hot rolling loads proposed by Sims [16].

A correlation of the values of MFS thus obtained with the specific controlled rolling conditions was performed to verify which process circumstances could promote austenite softening during the finishing stage.

\section{RESULTS AND DISCUSSION}

Figure 2 shows the evolution of the MFS values along the controlled rolling pass schedules. As can be observed in this figure, normal variations during the execution of the same nominal process conditions led to different trends for the MFS value observed in the F3 pass. Normally it is expected a continuous and monotonous increase in the values of MFS along the finishing stage of controlled rolling, but this was not always the case here: there was a slight decrease of $6 \mathrm{MPa}$ between the values of MFS for passes F2 and $F 3$ in the case of Figure 2a. In the case of Figure $2 b$ such decrease in MFS was not observed, although its increase was negligible: only $7 \mathrm{MPa}$. In general terms, it can be seen a steep increase of MFS at the beginning of the finishing stage until the $\mathrm{F} 2$ pass, occurring then a "plateau" in F3 pass and, from there, constant increase, but at a much slower pace than previously observed.
This discrepancy prompted a survey of the effective plate rolling conditions and their correlation with the different trends of MFS value in the F3 pass. Pass temperature versus accumulated strain plots, shown in Figure 3 , were made in order to identify which process conditions could lead to softening. Figure $3 \mathrm{a}, \mathrm{F} 2$ pass temperature versus cumulative strain in $\mathrm{FI}$ and $\mathrm{F} 2$ passes, was proposed to map the favorable conditions for a possible static recrystallization between $\mathrm{F} 2$ and $\mathrm{F} 3$ passes, while Figure $3 \mathrm{~b}, \mathrm{~F} 3$ pass temperature versus cumulative strain in $\mathrm{FI}, \mathrm{F} 2$ and $\mathrm{F} 3$ passes, had the same objective, but focusing on a possible dynamic recrystallization or austenite-to-ferrite transformation in $\mathrm{F} 3$ pass.

It can be observed that, in both cases, the softening in $\mathrm{F} 3$ pass has occurred when temperature in this pass was above approximately $950^{\circ} \mathrm{C}$, regardless of the previously accumulated strain. This softening could also occur at lower temperatures, down to $930^{\circ} \mathrm{C}$, provided that previously accumulated strain was large enough: above 0.45 for $\mathrm{FI}$ and $\mathrm{F} 2$ passes or 0.65 for $\mathrm{FI}, \mathrm{F} 2$ and $\mathrm{F} 3$ passes.

So, graphs at Figure 3 allow establishing an important recommendation: the finishing stage of controlled rolling of the steel studied here should be started at temperatures below $930^{\circ} \mathrm{C}$ to avoid any potential occurrence of any softening

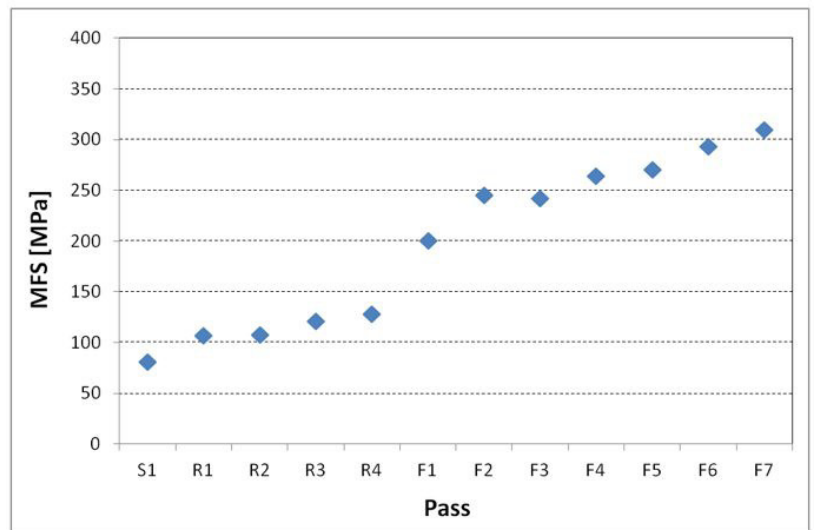

(a)

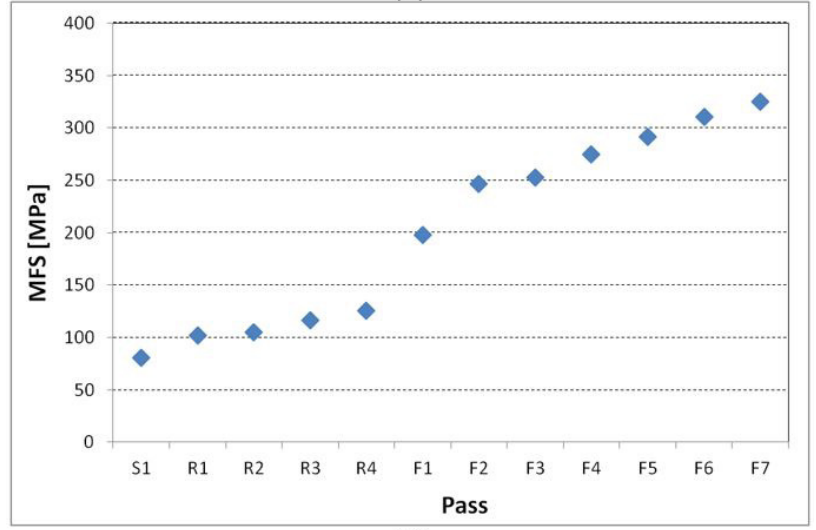

(b)

Figure 2. Evolution of MFS values observed along two pass schedules for the same steel and TMCP nominal conditions. Nevertheless, there were different trends for the MFS value in the F3 pass: (a) softening; (b) strain hardening (although slight). 


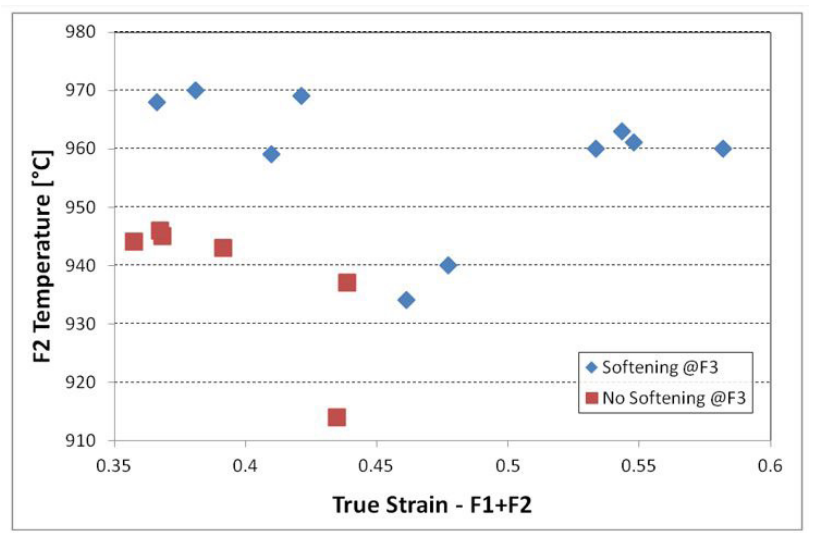

(a)

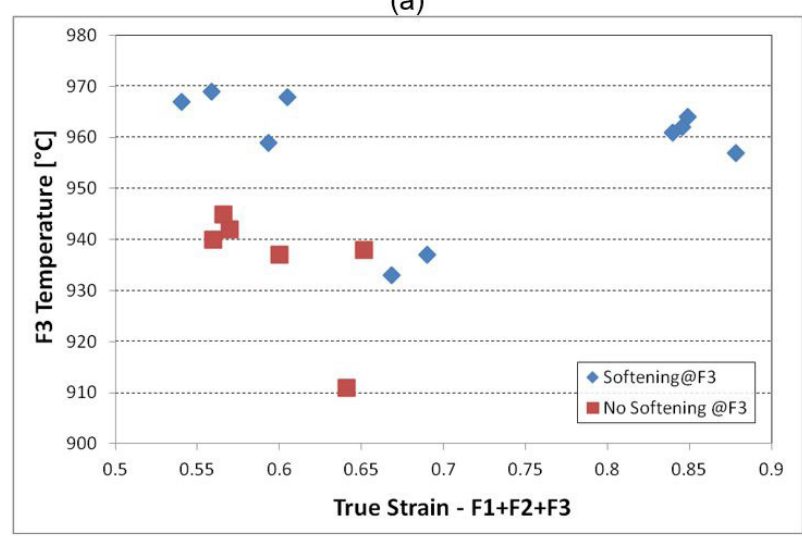

(b)

Figure 3. Softening condition maps in the $F 3$ pass: (a) temperature on $F 2$ pass versus accumulated strain on $\mathrm{F} 2$ and $\mathrm{F} 3$ passes; (b) temperature on the $\mathrm{F} 3$ pass versus accumulated strain on $\mathrm{FI}, \mathrm{F} 2$ and $\mathrm{F} 3$ passes.

between passes, in order to preserve homogeneity of the final microstructure and ensure a high toughness performance.

It would be interesting to know what kind of softening is occurring in the $\mathrm{F} 3$ pass - if static recrystallization in the interval between $\mathrm{F} 2$ and $\mathrm{F} 3$ pass, or dynamic recrystallization or ferrite transformation in $\mathrm{F} 3$ pass, but this is difficult to verify under industrial conditions. Calculations of microstructural evolution using models available in the literature [I 7$]$ cannot even predict the occurrence of austenite softening in the $F 3$ pass, most probably due to the lack of adequate equations to describe recrystallization and precipitation kinetics for $\mathrm{Nb}$ microalloyed steels with low Mn. However, a parallel additional experience, where time elapsed between passes $\mathrm{F} 2$ and $\mathrm{F} 3$ was purposely increased from $\mathrm{I} 0-\mathrm{I} 2$ seconds to 75 seconds, showed that there was no softening in the F3 pass as it would be expected, since this case fitted in the regions favorable to softening mapped in the graphs of Figure 3. On the contrary, in this case the value of MFS in the $\mathrm{F} 3$ pass was $12 \mathrm{MPa}$ higher than that in the $F 2$ pass, value higher than the $7 \mathrm{MPa}$ of variation that was usually observed in cases where softening did not occur. This fact seems to indicate that the softening observed in the $\mathrm{F} 3$ pass under the conditions mentioned here is probably due to some dynamic softening process, like dynamic recrystallization or even dynamic transformation [18], since a longer time available for restoration between $\mathrm{F} 2$ and $\mathrm{F} 3$ passes seems to have contributed to reduce the accumulated strain in austenite and avoided (or at least minimized) the dynamic softening in the $F 3$ pass.

One aspect to be considered here is the greater reduction of the $\mathrm{Nb}$ content dissolved in austenite due to the precipitation intensified by the low Mn content. Calculations performed through a microstructural evolution model [17], assuming the specific conditions of the TMCP performed here, but for a relatively high $\mathrm{Mn}$ steel, indicate that the loss of $\mathrm{Nb}$ in solid solution in the $\mathrm{F} 3$ pass can reach around $32 \%$, which would contribute to reduce the minimum deformation necessary for the occurrence of dynamic recrystallization. However, it should be noted that no specific equations are known yet to calculate the kinetics of recrystallization and precipitation of these new low Mn steels, which would probably indicate an even greater loss of solute $\mathrm{Nb}$. Another factor that may facilitate recrystallization is the lower content of $\mathrm{Mn}$ itself, since there will be less solute atoms in austenite to hinder the movement of the recrystallization interfaces, as previously reported [5].

A question then arises: why then did the test for determination of $T_{n r}$ performed in [13] not presented any softening of austenite below this temperature, which was approximately $1070^{\circ} \mathrm{C}$ ? A probable explanation for this fact is the continuous application of strain passes during this test. So, several of these passes were applied in the region of austenite partial recrystallization, that is, the range between the so called Recrystallization Limit Temperature (RLT) and Recrystallization Stop Temperature (RST). This fact, plus the relative long time intervals between passes $(30 \mathrm{~s})$, reduces the accumulation of residual strain that could promote an eventual recrystallization. As a matter of fact, double deformation tests showed the occurrence of partial recrystallization starting 10 seconds after the application of a 0.3 strain at $975^{\circ} \mathrm{C}[13]$. On the other hand, the industrial controlled rolling includes a holding period which prevents rolling while the plate shows temperatures within the range of partial recrystallization of austenite. The finishing stage started at relatively low temperatures, 940 to $970^{\circ} \mathrm{C}$, and time intervals between passes were relatively short, about 10 to $12 \mathrm{~s}$. Such conditions apparently allowed an accumulation of residual strain high enough to deflagrate dynamic recrystallization or ferrite transformation in the F3 pass.

\section{CONCLUSION}

When performing TMCP of Nb microalloyed steels it is necessary to ensure that its finishing stage occurs in such a way that no recrystallization of austenite occurs between passes. This contributes to an adequate level of microstructural homogeneity that ensures the achievement of good toughness characteristics in the final product. This is why the finishing stage of controlled rolling starts at 
temperatures below the RST, where recrystallization of austenite no longer occurs between the rolling passes. From a practical point of view, it can be considered that RST is 75 to $100^{\circ} \mathrm{C}$ below RLT (or $\mathrm{T}_{n \mathrm{n}}$ ). However, under specific process conditions, austenite softening was detected during the finishing stage of controlled rolling of a $\mathrm{Nb}$ microalloyed steel with low Mn content, even when this stage started at temperatures $100^{\circ} \mathrm{C}$ below the measured $T_{n r}$ value. This fact was attributed to the relatively low Mn content of this steel, which promotes an immediate and copious nucleation of $\mathrm{NbCN}$ precipitation in the dislocations after hot deformation, preventing the recovery of austenite and increasing the thermodynamic potential for its recrystallization. The most evident solution to this problem, as shown by the results of this work, is an even greater lowering of the start finishing temperature of controlled rolling in order to restrict the eventual occurrence of austenite recrystallization, despite its higher thermodynamic potential.

\section{REFERENCES}

I Gorni AA, Silveira JHD, Camey K, Reis EG. Austenite partial recrystallization in the finishing stage of controlled rolling of niobium microalloyed steels with low manganese. In: Proceedings of the I I th International Rolling Conference: ABM Week; 2019; São Paulo. São Paulo: ABM; 2019.

2 Jansto S. The integration of process and product metallurgy in niobium bearing steels. Metals. 20I8;8(67I):I-20.

3 Gorni AA, Reis JSS, Silva CNP, Cavalcanti CG. Otimização da composição química e do processo de laminação controlada de chapas grossas navais. In: Anais do $32^{\circ}$ Seminário de Laminação: Processos e Produtos Laminados e Revestidos; 1995; Curitiba. São Paulo: Associação Brasileira de Metalurgia e Materiais; 1995. p. 373-392.

4 Gray JM. Ultra low manganese high toughness HTP sour service linepipe steel. In: Proceedings of the Microalloyed Pipe Steels for the Oil \& Gas Industry Congress; 20I3; Moscow, Russia. Moscow: CBMM; 20I3. I4 p.

5 Maehara Y, Kunitake T, Fujino N. The effect of alloying elements on the static recrystallization of mild steels in the austenite range. Tetsu To Hagane. 1981;67:362-37I.

6 Cho SH, Bang KB, Jonas JJ. Effect of manganese on recrystallisation kinetics of niobium microalloyed steel. Materials Science and Technology. 2002; 18:389-395.

7 Lotter U, Schmitz HP, Zhang L. Application of the metallurgically oriented simulation system "TKS-StripCam" to predict the properties of hot strip steels from the rolling conditions. Advanced Engineering Materials. 2002;4:207213.

8 Koyama S, Ishii T, Narita K. Effects of Mn, Si, Cr and $\mathrm{Ni}$ on the solution and precipitation of niobium carbide in iron austenite. Journal of the Japanese Institute of Metals. I97I;35: I089- 1094.

9 Akben MG, Weiss I, Jonas JJ. Dynamic precipitation and solute hardening in a $\mathrm{V}$ microalloyed steel and two $\mathrm{Nb}$ steels containing high levels of Mn. Acta Metallurgica. 198I;29: I I I-I2I.

I0 Karmakar A, Biswas S, Mukherjee S, Chakrabarti D, Kumar V. Effect of composition and thermomechanical processing schedule on the microstructure, precipitation and strengthening of $\mathrm{Nb}$-microalloyed steel. Materials Science and Engineering A. 2017;690:158-169.

I I Miao CL, Shang CJ, Zhang GD, Zhu GH, Zurob H, Subramanian S. Studies on softening kinetics of niobium microalloyed steel using stress relaxation technique. Frontiers of Materials Science in China. 2010;4:197-201.

I2 Subramanian S, Zurob H, Miao C, Shang C. Studies on softening kinetics of low manganese steel microalloyed with niobium for high-strength sour service ERW pipe. In: Proceedings of the International Symposium on the Recent Developments in Plate Steels; 201 I; Winter Park, Colo. USA. Warrendale : Association for Iron \& Steel Technology; 201 I. p. 365-374.

13 Oliveira NJL, Andrade MS, Castro CSB, Escobar DP, Borba EC, Silva JCP, et al. Precipitação de Nb(C,N) durante a laminação a quente de chapas grossas de um aço com baixo Mn e Alto Nb. Belo Horizonte: Centro de Inovação e Tecnologia SENAI-FIEMG; 2017. 102 p. Relatório Final de Projeto.

I4 Boratto F, Barbosa R, Yue S, Jonas JJ. Effect of chemical composition on the critical temperatures of microalloyed steels. In: Thermec-88: Proceedings of the International Conference on Physical Metallurgy of Thermomechanical Processing of Steels and Other Metals; 1988; Tokyo, Japan. Tokyo: Iron and Steel Institute of Japan; 1988. p. 383-390.

I5 Bai D, Bodnar R, Ward J, Dorricott J, Sanders S. Development of discrete X80 line pipe plate at SSAB Americas. In: Proceedings of the International Symposium on the Recent Developments in Plate Steels; 20 I I; Winter Park, Colo. USA. Warrendale: Association for Iron and Steel Technology; 20I I. p. I3-22. 
I6 Sims RB. The calculation of roll force and torque in hot rolling mills. Proceedings of the Institution of Mechanical Engineers. 1954;168:191-214.

17 Pereda B, Rodriguez-lbabe JM, López B. Improved model of kinetics of strain induced precipitation and microstructure evolution of Nb microalloyed steels during multipass rolling. ISIJ International. 2008;48: I457-I 466.

18 Rodrigues SF, Aranas C Jr, Wang T, Jonas JJ. Dynamic transformation of an X70 steel under plate rolling conditions. ISIJ International. 2017;57:162-I69.

Received: 15 Nov. 2019

Accepted: 8 Dec. 2019 